\title{
STABILIZED DOMAIN-WALL PINNING IN A CONSTRICTED NANOWIRE
}

\author{
STABILIZACIJA PRIPENJANJA STEN DOMEN V STISNJENI \\ NANOŽICI
}

\author{
Basutkar Umamaheshwar Venkata Prashanth', Mohammed Riyaz Ahmed ${ }^{2 *}$ \\ School of Electronics and Communication Engineering, REVA University, Bengaluru 560064, India \\ Prejem rokopisa - received: 2019-03-14; sprejem za objavo - accepted for publication: 2019-11-08
}

doi:10.17222/mit.2019.057

\begin{abstract}
The typical characteristics of spin that relate to logical applications and memory are part of domain walls, where they are utilized as information carriers. Magnetic skyrmions also fall under the above category and their unique topology enables them to exhibit distinct characteristics of a dynamic nature in comparison with domain walls. A novel method of accurately binding a domain wall with a magnetic nanowire is proposed. The domain wall is stapled, at the desired position, to the proposed stepped nanowire, forming a new structure with a simple offset of two single nanowires. The domain wall can be precisely stabilized by creating a stepped nanowire. The parameters of the nanowire such as the size of the step, the properties of the materials and the dimensions are strongly dependent on the critical current regarding the depinning of the domain wall. A low depinning current is required for a wide nanowire. We address the current-induced domain wall in a compressed nanowire computationally via a computer algorithm and simulate the pinning of the domain wall in the compressed region via a graphic-processing-unit (GPU) accelerated micromagnetic simulation framework. Further, in the paper, we investigate the design of the device physics, multiple-bit per single cell memory, utilized in high-performance computing and vision systems.

Keywords: magnetic memory, magnetization reversal, saturation magnetization, magnetic domain wall
\end{abstract}

S stenami domen označujemo tipično strukturo spinov, ki je pomembna za logične operacije in spomin, kjer se le-te uporabljajo kot nosilci informacij. V primerjavi s stenami domen vrtinčaste strukture (magnetni skirmioni), sodijo v podobno kategorijo in njihova topologija omogoča razjasnitev edinstvenih značilnosti dinamične narave. Avtorji članka predlagajo novo metodo za natančno vezanje stene domen v magnetni nanožici. Stena domen je pripeta na željenem položaj, v predlagani stopničasti žici, s tvorbo nove strukture $\mathrm{z}$ enostavnim zvijanjem dveh posameznih nanožičk. Stena domene se lahko natančno stabilizira s kreiranjem stopničaste nanožičke. Parametri nanožičke, kot so: velikost koraka, lastnosti materialov in njihove dimenzije, so močno odvisni od kritičnega toka za odklepanje stene domene. Za odklepanje širokih nanožičk je potreben manjši tok. Avtorji so računsko, s pomočjo računalniškega algoritma, razložili proces tokovno-inducirane stene domen v stisnjeni nanožici in simulirali pripenjanje stene domen, v stisnjenem področju, s pomočjo grafične procesne enote (GPU) pospešenega mikromagnetnega simulacijskega ogrodja. Nadalje avtorji v članku opisujejo še raziskavo dizajna fizike naprave, značilnosti naprave in logično strukturo zahtevane nanožičke za razvoj večbitnega enoceličnega spomina, uporabnega za visoko-zmogljivo izračunavanje in sisteme vizualizacije.

Ključne besede: magnetni spomin, reverzna magnetizacija, magnetizacija nasičenja, magnetne stene domen

\section{INTRODUCTION}

In 2016, S. R. Sbiaa et al. ${ }^{14}$ carried out an extensive research and proposed a novel technique for attaching a domain wall (DW) with the appropriate orientation to a generic model of a magnetic nanowire. The current paper further extends this work by investigating the variation in the parameters and modeling the generic model of a nanowire, carrying out simulations of the magnetization profile in a GPU-accelerated framework. Magnetic DWs exhibiting magnetic nanowires are studied extensively with respect to the magnetic memory of a high-density computing paradigm. ${ }^{1}$ It is necessary to control the positions of domain walls to provide for the development of logical-architecture magnetic-memory devices with multiple bits per single cell. ${ }^{2}$ Controlling DWs defines the starting point for magnetic-random-access-memory (MRAM) ${ }^{3}$ magnetic-nanowire-device concepts ${ }^{4}$ lower-

*Corresponding author's e-mail:

riyaz@reva.edu.in (Mohammed Riyaz Ahmed) ing the energy cost of the DWs so that notches can act as pinning sites. One of the pinning schemes for DWs is the asymmetric control of a DW injection; with this scheme, an artificial notch is attached to permalloy (Ni80Fe20) nanowires, ${ }^{16}$ with a nanobar perpendicular to it and an asymmetrical pad. ${ }^{5}$ The variations are due to the magnetization reversal in the devices of a magneto-resistive nature with more than one independent layer. ${ }^{6}$ The control of DW positions is achieved with various scheme attributes of the binding.

In an experimental set-up, creating glitches of artificial nature, i.e., constrictions are utilized to output the potential to the region, to which the domain wall can be stapled. $^{7}$ To design binding sites with the etching technique is a challenging task since it requires a high persistence of the etching. The requirement here is that the proliferation of the irradiated region is always greater than the expected one, which is typical for devices with widths of tens of nanometer. On the other hand, it is simple to design a nanowire. It is noteworthy that the 


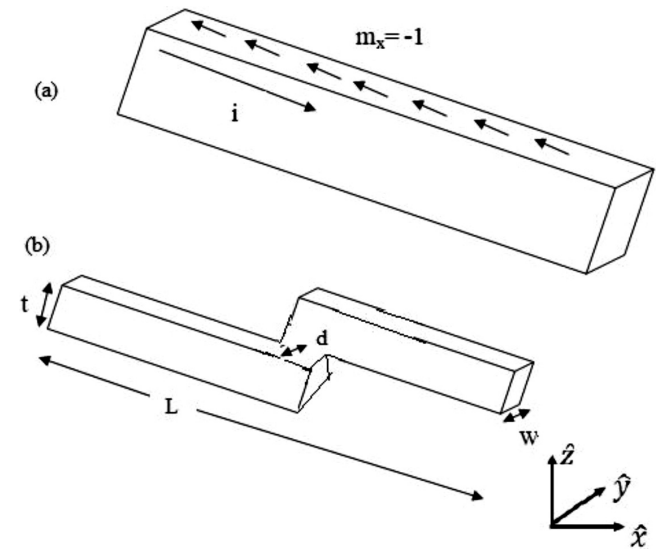

Figure 1: a) Schematic of a conventional nanowire and b) a proposed constricted type of a nanowire where constriction can be used for forming a step and binding a domain wall ${ }^{14}$

size of the cleft has to be relatively smaller than the thickness of the nanowire. ${ }^{8}$ Figure 1a depicts a conventional nanowire, in which the magnetization is directed in the horizontal $\mathrm{x}$-direction and the current polarized with the spin flows along the length of the nanowire in the horizontal $\mathrm{x}$-direction. In Figure 1b between multiple regions one step is formed. This approach is simpler than forming a cleft in the desired position and it is noteworthy that a highly accurate size of a step can be obtained using a CAD sketch aiming at resisting vulnerability. ${ }^{9}$

\section{THEORETICAL MODEL}

As current passes through a ferromagnetic material, electrons polarize due to the angular momentum transfer to the free layer resulting in the spin-transfer torque of the magnetic material. ${ }^{10}$ The current-induced DW motion is investigated by numerically solving the LandauLifshiz-Gilbert(LLG) equation as seen in Equation (1) using the public object oriented micro-magnetic framework (OOMMF).

$$
\frac{\mathrm{d} s}{\mathrm{~d} t}=S \cdot \frac{\delta H[S]}{\delta S}-j \frac{\partial S}{\partial z}+\beta j S \cdot \frac{\partial S}{\partial z}+\alpha S \cdot \frac{\partial S}{\partial t}
$$

Here, Hamiltonian $H(\mathrm{~S})$ is a function of the normalized magnetization field $\mathrm{S}(\mathrm{Z}) ; \alpha=\alpha_{0} / M^{2}$ and $\alpha_{0}$ is the Gilbert damping constant; $\beta=\beta_{0} / M^{2}$ being the constant of the non-adiabatic current; time is measured in units of the gyro magnetic ratio $\gamma=\gamma_{0} \mid \mathrm{e} / /(2 m c)$; and the current density $J_{\mathrm{c}}$ is measured in units of $\mathrm{a}^{3} /\left(2 \mathrm{eM} \gamma_{0}\right)$ where $\mathrm{a}$ is the lattice constant.

The standard values of material parameters of the simulated material are as seen in Figure 2 as the red box. The system must be appropriately initialized in order to obtain a DW in the relaxed state. The standard values of the initial magnetization are set to be in the extremal corners of the $(0 ; 0 ; 1)$ direction for $x<0: 4 \mathrm{Lnm}$, in the extremal corners of the $(1 ; 0 ; 0)$ direction for $0: 4 \mathrm{Lnm}<$ $x<0$ :6Lnm, and in the extremal corners of the $(0 ; 0 ; 1)$



Figure 2: Theoretical models of the material parameters of the simulated material

direction for $x>0: 6 \mathrm{Lnm}$. As seen in Figure 3, the system is initially relaxed in the zero external magnetic field and then, from the obtained equilibrium configuration, the magnetization dynamics is simulated for each of the two different external magnetic fields: $H_{1}=$ $(-24.6,4.3,0.0) \mathrm{mT}$ and $H_{2}=(-34.5,-6.3,0.0) \mathrm{mT}$. With the obtained relaxed magnetization, the evolution of magnetization can be simulated for the two different external magnetic fields and we obtain the average magnetization-time evolution components, as illustrated in Figure 3a.
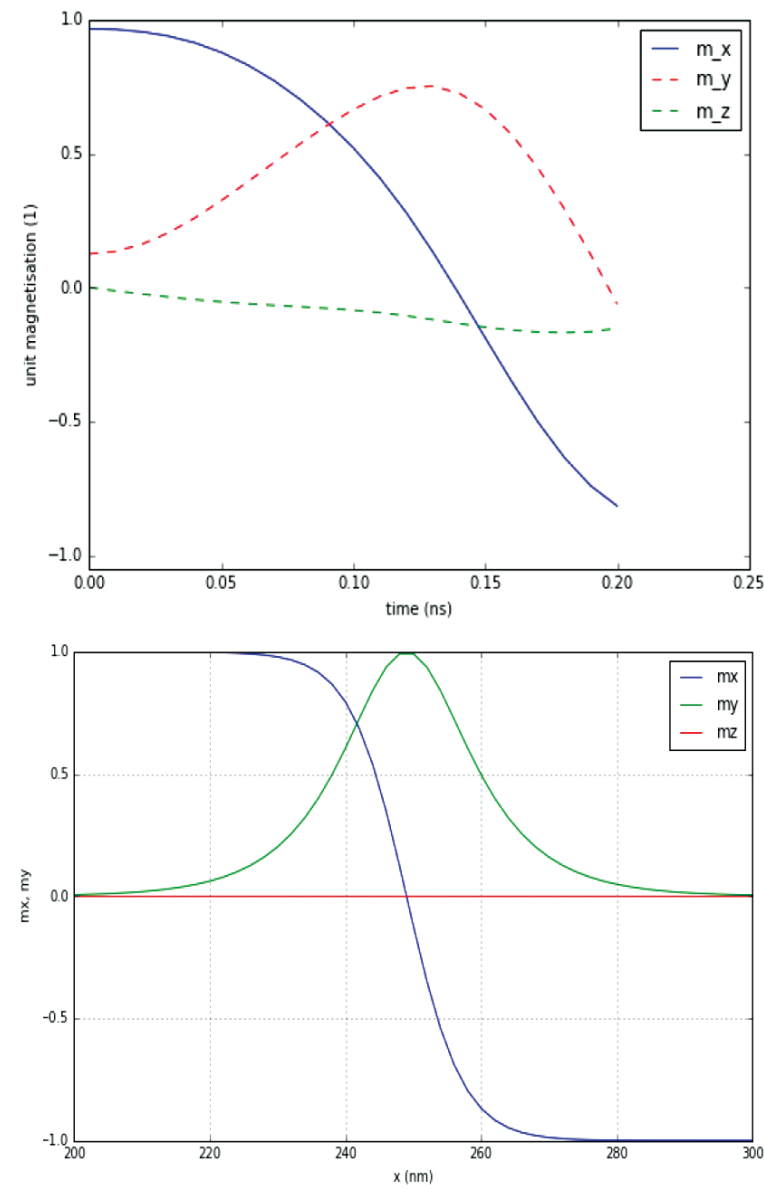

Figure 3: a) Average magnetization for the basic thin-film cuboid ${ }^{15}$, b) magnetization profile computed for the one-dimensional domain wall $^{15}$ 

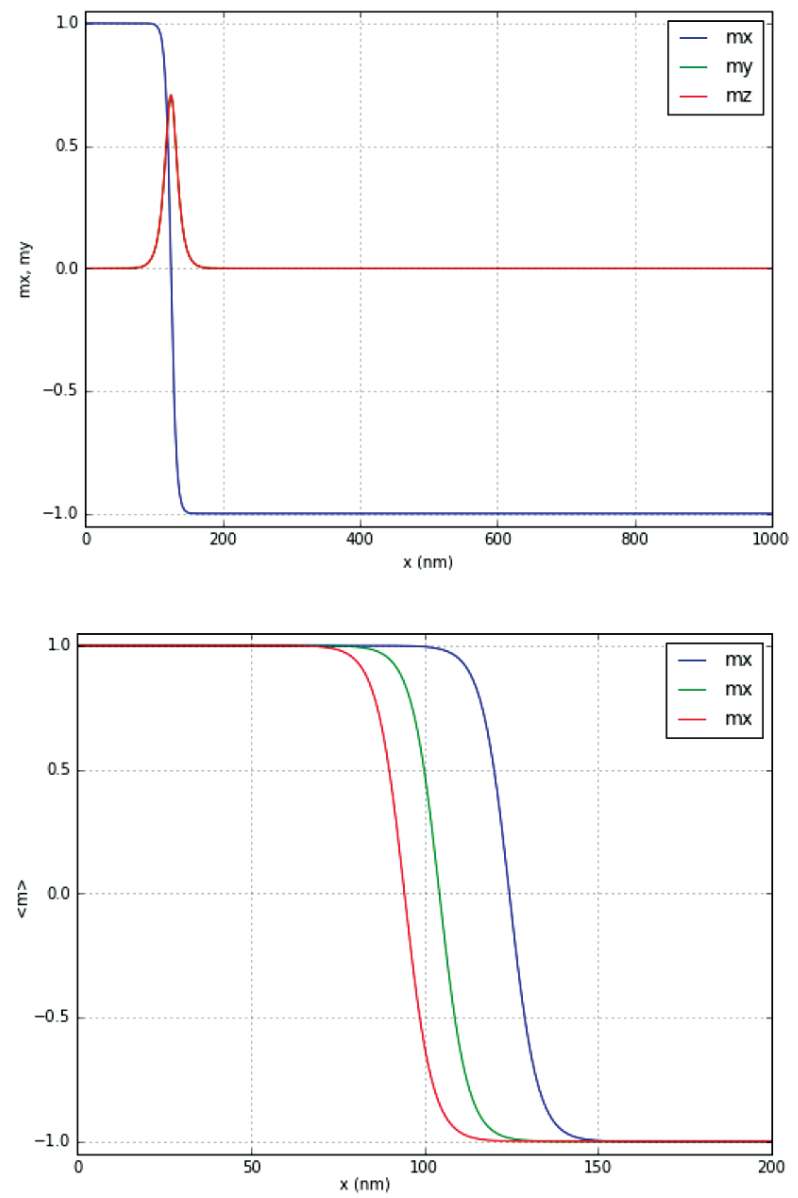

Figure 4: a) Simulation of the DW equilibrium state in the presence of spin-polarized current, b) application of spin-polarized current for $\left|m_{\mathrm{z}}\right|$ component to observe the DW motion ${ }^{15}$

In the second case, the simulated sample is a $1 \mathrm{D}$ domain wall with the device geometry and material parameters as depicted in Figure $\mathbf{3 b}$ where the domain-wall



Figure 5: Flow diagram of the Hamiltonian used for different cases encountered profile $^{11}$ is computed for a one-dimensional domain wall with $L=200 \mathrm{~nm}$. The magnetization is initialized, the system is relaxed to its equilibrium state and the magnetization profile is plotted as illustrated above in Figure 3b.

The third case is depicted in Figure $\mathbf{4 a}$ and $\mathbf{4 b}$. Here, the simulated sample is a 1D-nanowire cuboid, whose device geometry and material parameters are illustrated in Figure 2, represented by the blue box. After the system is relaxed to a domain wall, a spin-polarized current density with $J_{\mathrm{C}}=1 \times 10^{12} \mathrm{~A} / \mathrm{m}^{2}$ is applied in the positive $\mathrm{x}$-direction in the extremal corners of $(1,0,0)$. The DW is at the maximum value of $\left|m_{\mathrm{z}}\right|$ or $\left|m_{\mathrm{y}}\right|$; consequently, the DW position is maximum $\left|\mathrm{m}_{\mathrm{z}}\right|$ at $x=$ 124 with the obtained domain-wall equilibrium state, and the motion is simulated in the presence of a spinpolarized current as depicted in Figure $\mathbf{4 b}$.

We compare the initial state with the ones occurring after the spin-polarized current was applied to the $\left|m_{\mathrm{x}}\right|$ component to observe the domain-wall motion and compute it until the system reaches nearly $5 \mathrm{~ns}$ to improve the effect. The simulated sample has the following dimensions: length $L=200 \mathrm{~nm}$, width $d=125 \mathrm{~nm}$ and thickness $t=3 \mathrm{~nm}$. The magnetization dynamics is governed by the (LLG) equation:

$$
\frac{\mathrm{d} \mathbf{m}}{\mathrm{d} t}=-\gamma_{0}\left(\mathbf{m} \times H_{e f f}\right)+\alpha\left(\mathbf{m} \cdot \frac{\mathrm{d} \mathbf{m}}{\mathrm{d} t}\right)
$$

where $\gamma_{0}=\left(2.211 \times 10^{5} \mathrm{~mA}^{-1} \mathrm{~s}^{-1}\right)$ is the gyro-magnetic ratio and $\alpha_{0}$ is the Gilbert damping.

Figure 5 illustrates the Hamiltonian applied in order to derive LLG Equation (2) from Equation (1) and provides a brief presentation of the comparison between the two equations. Also, it depicts a useful property of the micromagnetic simulation, in which the ground states can be observed by integrating the LLG forward to convergence, enhanced by considering physically huge values of $\alpha$. The simulations were carried out with a finite-difference micromagnetic code used by Fidimag ${ }^{15}$.

\section{RESULTS}

The algorithm steps as illustrated in Figure 6 with the parameters required for simulating the domain-wall

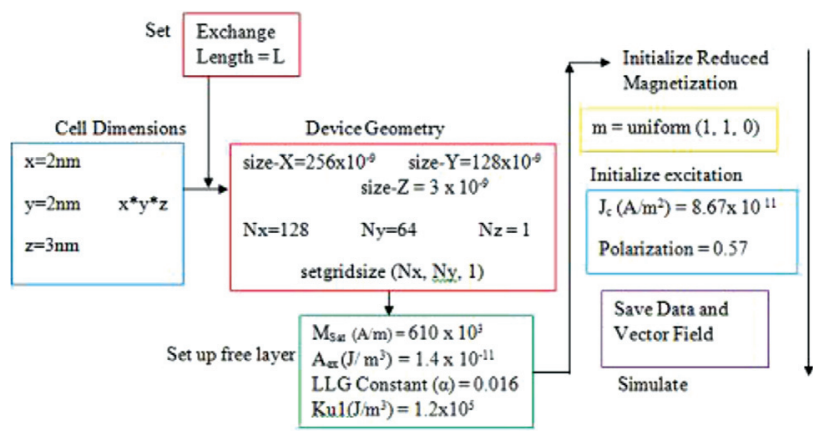

Figure 6: Flow diagram of the simulation set-up 


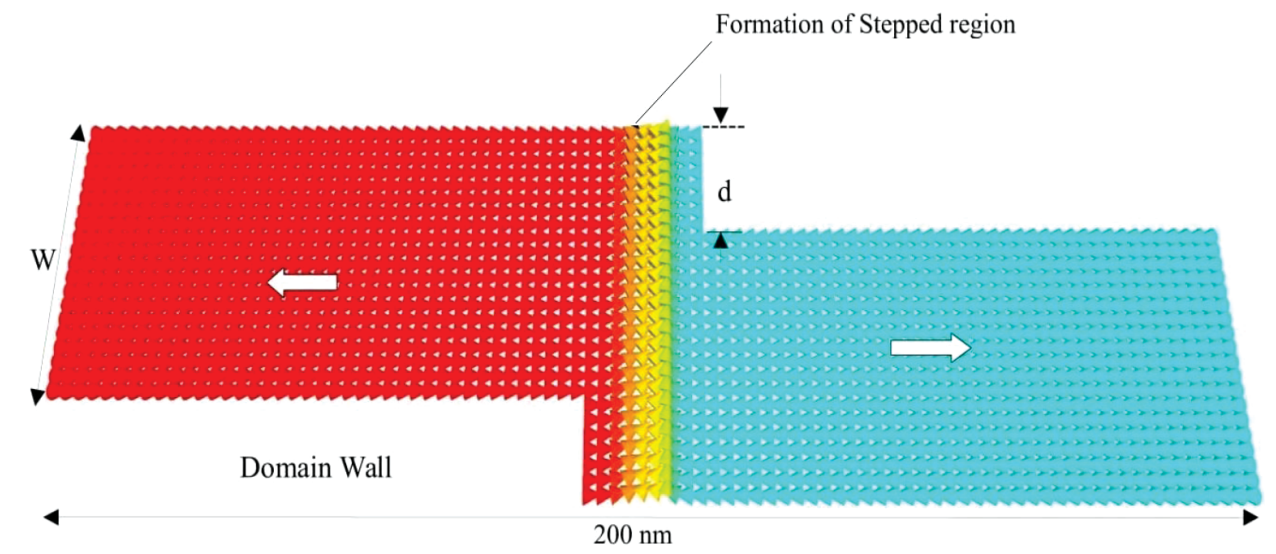

Figure 7: Simulation of a constricted nanowire with a stabilized magnetic domain wall

oscillation in the constricted nanowire in MUMAX 3.9.1c (CUDA 9020 GeForce GTX 1050) allow us to obtain the result shown in Figure 7 where we can see that the domain wall is bound to the constricted region of the nanowire. ${ }^{12}$ The domain wall was blocked at the constricted region of $d=15 \mathrm{~nm}$ and with the spin polarization of the applied current; with the damping constant, the polarized electric current flows along the positive $\mathrm{x}$-direction. At low current densities, an extrinsic binding regime appears and after a few damped oscillations, the domain wall becomes stable. ${ }^{13}$ The slope of mobility curves is lowered due to an effective damping parameter such as $\left(\alpha_{\text {eff }}\right)$, which consists of a constant intrinsic part and an extrinsic part, dependent on the disorder strength. This work is expected to speed up the development of the magnetic racetrack memory with a promising logic architecture such as the domain-wall-gated skyrmion logic architecture. ${ }^{14}$

\section{CONCLUSIONS}

In this research, we implemented the oscillation of a stabilized magnetic domain wall in a constricted nanowire through a novel method of accurately pinning a domain wall in the desirable position and stabilized it precisely using a stepped nanowire. In order to enhance the reliability of future nanowire-based spintronic devices, the domain-wall motion of magnetic nanowires must be thoroughly investigated. This fundamental work paves the way for the development of novel skyrmionbased spintronic devices and high-dimensional memory architectures.

\section{REFERENCES}

${ }^{1}$ D. A. Allwood, G. Xiong, C. C Faulkner, D. Atkinson, D. Petit, R. P. Cowburn Magnetic DW Logic, Science, 309 (2005), 1688-92, doi:10.1126/science. 1108813

${ }^{2}$ S. S. Parkin, M. Hayashi, L. Thomas, Magnetic DW Racetrack Memory, Science, 320 (2008), 190-4, doi:10.1126/science.1145799

${ }^{3}$ M. Yamanouchi, J. Ieda, F. Matsukura, S. E Barnes, S. Maekawa, H. Ohno, Universality Classes for DW Motion in the Ferromagnetic Semiconductor (Ga,Mn)As, Science, 317 (2007)
${ }^{4}$ Muller, J. Walowski, M. Djordjevic, G. X Miao, A. Gupta, A. V. Ramos, K. Gehrke, V. Moshnyaga, K. Samwer, J. Schmalhorst, A. Thomas, Spin polarization in half-metals probed by femtosecond spin excitation, Nature Materials, 8 (2009), 56-61, doi:10.1038/ nmat 2341

${ }^{5}$ R. Sbiaa, R. W. Chantrell, Domain wall oscillations induced by spin torque in magnetic nanowires, Journal of Applied Physics, 117 (2015) 5, doi:10.1063/1.4906438

${ }^{6}$ L. Thomas, M. Hayashi, X. Jiang, R. Moriya, C. Rettner, S. Parkin, Resonant Amplification of Magnetic DW Motion by a Train of Current Pulses, Science, 315 (2007), doi:315.1553-6.10.1126/ science. 1137662

${ }^{7}$ O. Boulle, S. Rohart, L. D. Buda-Prejbeanu, E. Jué, I.M Miron, S. Pizzini, J. Vogel, G. Gaudin, A. Thiaville, DW Tilting in the Presence of the DMI in Out-of-Plane Magnetized Magnetic Nanotracks, Phys. Rev. Lett., 111 (2013), doi:10.1103/PhysRevLett.111.217203

${ }^{8}$ S. J. Noh, Y. Miyamoto, M. Okuda, N. Hayashi, Y. Keun Kim, Effects of notch shape on the magnetic domain wall motion in nanowires with in-plane or perpendicular magnetic anisotropy, Journal of Applied Physics, 111 (2012), doi:10.1063/ 1.3677340

${ }^{9}$ R. Sbiaa, R. Law, S. Y. Lua, E. L. Tan, T. Tahmasebi, C. C. Wang, S. N. Piramanayagam, STT switching for multi-bit per cell magnetic memory with PMA, Applied Physics Letters, 99 (2011) 9, doi:10.1063/1.3632075

${ }^{10}$ J. Rachid Sbiaa, Frequency selection for magnetization switching in spin torque magnetic memory, J. Phys. D: Appl. Phys., 48 (2015), doi:10.1088/0022-3727/48/19/195001

${ }^{11}$ T. Koyama, D. Chiba, K. Ueda, K. Kondou, H. Tanigawa, S. Fukami, T. SuzukI, N. Ohshima, N. Ishiwata, Y. Nakatani, K. Kobayashi, Observation of the intrinsic pinning of a magnetic domain wall in a ferromagnetic nanowire, Nature Materials, 10 (2011), 194-197

${ }^{12}$ S. D. Kim, Y. Miyamoto, M. Okuda, N. Hayashi, Y. Keun Kim, Effects of notch shape on the magnetic DW motion in nanowires with in-plane or PMA, Journal of Applied Physics, 111 (2012), doi:10.1063/1.3677340

${ }^{13}$ S.-H. Huang, C.-H. Lai, Domain-wall depinning by controlling its configuration at notch, Appl. Phys. Lett., 95 (2009), doi:10.1063/ 1.3187530

${ }^{14}$ R. Sbiaa, M. Al Bahri, Constricted nanowire with stabilized magnetic domain wall, Journal of Magnetism and Magnetic Materials, 411 (2016), 113-115, doi:10.1016/j.jmmm.2016.03.043

${ }^{15}$ M.-A. Bisotti, D. Cortés-Ortuño, R.A Pepper, W. Wang, M. Beg, T. Kluyver, H. Fangohr, Fidimag, J. of Open Research Software, 6 (2018) 10

${ }^{16} \mathrm{~S}$. Gerretsen, STT in Ferromagnetic Materials, Dept. of Physics and Astronomy, University of California, 2008, Los Angeles, Ca, 90095 